\title{
ETIKA BISNIS TAK BERJALAN DI INDONESIA: ADA APA DALAM CORPORATE GOVERNANCE?
}

\author{
Niki Lukviarman \\ Fakultas Ekonomi Universitas Andalas Padang \\ Abstract
}

\begin{abstract}
Tulisan ini membahas berbagai kendala penerapan konsep CG (Corporate Governance) di Indonesia, dari sudut pandang etika bisnis. Bagian pertama meninjau ulang makna/pengertian konsep CG. Bagian kedua membahas perkembangan konsep CG berkaitan dengan pandangan umum mengenai pelaksanaan CG di Indonesia. Berbagai kendala penerapan CG di Indonesia, khususnya yang berkaitan dengan etika bisnis, dibahas pada bagian berikutnya, dan diakhiri dengan bagian penutup.

[I]n the great 'chessboard' of human society, every single piece has a principle of motion of its own, altogether different from that which the legislature might chuse to impress upon it. If those two principles coincide and act in the same direction, the game of human society will go on easily and harmoniously, and is very likely to be happy and successful. If they are opposite or different, the game will go on miserably, and the society must be at all times in the highest degree of disorder. Adam Smith, The Theory of Moral Sentiments (1759, p. 234)
\end{abstract}

\section{MASALAH}

Berbagai isu yang berhubungan dengan Corporate Governance disingkat CG- menjadi populer di Indonesia di penghujung abad ke-20, tepatnya setelah terjadinya krisis ekonomi dalam bulan Juni 1997. Isu semacam itu menguat kembali setelah runtuhnya beberapa raksasa bisnis dunia seperti Enron and WorldCom di $\mathrm{AS}^{1}$, dan tragedi jatuhnya $\mathrm{HIH}$ dan One-tel di Australia pada permulaan abad ke 21. Isu CG semakin gempar setelah berbagai lembaga keuangan multilateral, seperti World Bank dan ADB mengungkap bahwa penyebab krisis keuangan yang melanda berbagai negara, terutama di Asia, tak lain adalah buruknya pelaksanaan Corporate Governance. Dalam hal ini, Indonesia merupakan negara yang paling menderita serta paling lambat bangkit dari dampak tersebut (ADB 2000).

Di Indonesia, krisis ekonomi ini telah berkembang dan bersifat multi dimensi, karena diikuti krisis politik serta berbagai masalah dalam negeri lainnya. Hal ini diperparah oleh lemahnya mekanisme berbagai ins-

1 Menyusul skandal dua perusahaan besar ini, pemerintah A.S. mengeluarkan aturan baru yang dikenal dengan The Sarbanes-Oxley Act of 2002 (SOA Act) pada tanggal 30 Juli 2002. Aturan baru ini dianggap sebagai the most seeping change in corporate governance and the regulator of accounting practices' semenjak dikeluarkannya the Securities and Exchange Act of 1934. SOA Act ini pada intinya memberikan penekanan pada prinsip keterbukaan (disclosure), perlunya komite audit (audit committees) yang beranggotakan komisaris independen, serta larangan untuk memberikan pinjaman kepada dewan komisaris perusahaan. Aturan ini menekankan (imposes) hukuman yang lebih berat untuk setiap tingkat pelanggaran yang dikategorikan sebagai corporate wrongdoing seperti: criminal, fraud dan other wrongful act. 
titusi penyangga sistem perekonomian negara. Keadaan menjadi semakin parah karena rendahnya kadar penegakan hukum sebagai benteng terakhir yang diharapkan dapat menjamin tegaknya aturan dan berjalannya sistem yang ada. Apalagi, larinya modal dalam negeri ke negara lain (capital flights) sangat besar jumlahnya, sehingga secara teknis menyebabkan Indonesia dianggap bangkrut.

Dalam kondisi demikian, tidak mengherankan bila lembaga keuangan terbesar di dunia (IMF) datang menawarkan program penyelamatan ekonomi kepada Indonesia. Lembaga ini mensyaratkan adanya perbaikan serta peningkatan praktik CG di Indonesia (Kurniawan \& Indriantoro 2000). Letter of intent yang ditandatangani pemerintah RI bersama lembaga ini menjadi tonggak awal dimulainya reformasi sistem CG nasional secara legal-formal2. Hal ini diwujudkan melalui pembentukan 'Komite Nasional Mengenai Kebijakan Corporate Governance' melalui Keputusan Menteri Koordinator Bidang Ekuin tahun 1999. Pada tahun berikutnya, dihasilkan kode etik untuk pelaksanaan CG melalui 'Code for Good Corporate Governance' (2000). Namun demikian, hingga tulisan ini selesai, penerapan kode etik itu belum bersifat wajib (mandatory) atau masih bersifat himbauan (optional) dan hanya ditujukan pada perusahaan yang tercatat di pasar modal. Masalahnya sekarang, Corporate Governance itu harus seperti apa?

\section{KENAPA CORPORATE GOVERNANCE?}

Dari paparan di atas, pertanyaan paling mendasar yang muncul dari kalangan umum adalah; kenapa berbagai praktik yang dilakukan perusahaan (corporate) berhubungan dengan krisis ekonomi-nasional secara menyeluruh. Salah satu alternatif jawaban atas pertanyaan ini dapat dilihat dari sudut pandang organisasi sebagai sebuah sistem. Fenomena ini dapat diamati melalui pemahaman bahwa sebuah sistem terdiri dari berbagai komponen (sub-system) seperti "perusahaan" dan kelembagaan (institusi) lainnya yang akan berinteraksi di dalam sistem tersebut. Sebagaimana kutipan yang disajikan di awal tulisan ini, Adam Smith mengibaratkan sistem ini melalui permainan papan catur besar. Setiap bidak yang berada di papan permainan mempunyai fungsi/peranan serta aturan main (motion) yang berbeda-beda. Misalnya, fungsi serta aturan main bidak 'gajah' dengan 'kuda' adalah berbeda, dan pemain berperan untuk menjaga agar

2 Di bidang hukum dan perundang-undangan reformasi CG diikuti dengan dihasilkannya undangundang kebangkrutan (bankcruptcy law) diikuti dengan dibentuknya special commecial court di tahun 1998 (Robins 2002). Walaupun terdapat perbaikan terhadap struktur perundang-undangan yang berlaku, menurut Lindsey (2002) berbagai perangkat hukum yang ada masih dipengaruhi oleh hukum yang dibangun oleh Belanda. 
semua bidak berfungsi/berperan dan berjalan sesuai dengan aturan mainnya, sehingga permainan dapat dilaksanakan secara baik. Sebagai sebuah sistem, permainan akan menjadi lancar dan menarik, jika semua komponennya berjalan sesuai dengan fungsi atau peranannya dan berinteraksi secara harmoni. Sebaliknya, jika bidak dan pemain tidak mengikuti aturan main yang ditetapkan, akan terjadi kekacauan (disorder) dengan akibat tidak tercapainya tujuan permainan yang diinginkan. Pada intinya, sistem adalah adalah kesatuan antar komponen sehingga bila satu komponen berjalan menyimpang, maka system akan menjadi kacau.

Dari metafora di atas, jelas bahwa CG sebenarnya merupakan suatu sistem ${ }^{3}$, yang terdiri dari berbagai perangkat/kelembagaan serta aturan main (code of conduct) dan hukum yang dibutuhkan untuk menjaga keseimbangan (cheks and balances) agar sistem dapat bekerja secara optimal. Secara umum, CG dapat dibedakan dengan fenomena manajemen lainnya melalui pemahaman istilah sederhana berikut. Manajemen dapat diartikan sebagai suatu mekanisme yang akan menjamin bahwa segala sesuatu "dilakukan secara benar" (doing things right) atau manajemen berhubungan dengan aktivitas manages the "things" (Takala 1998). Sementara CG adalah mekanisme 4 untuk "melakukan sesuatu yang benar, secara benar" (doing the right things right), dengan penekanan makna pada "the right things". Melalui pembedaan yang sangat mendasar ini, terlepas dari setuju atau tidaknya seseorang, pembelajaran yang bisa dipetik dalam hal tersebut dapat dijelaskan sebagai berikut.

Konsep manajemen, merupakan hal yang sudah dikenal, diterapkan untuk jangka waktu panjang dan berkembang secara pesat. Bahkan dalam beberapa tahun terakhir, berbagai teknik manajemen telah menjadi semakin canggih dan variatif. Tetapi konsep ini dianggap belum mampu menjawab pertanyaan; kenapa dengan manajemen yang canggih sekalipun, perusahaan kelas dunia seperti Enron bisa runtuh? Salah satu kelemahan dari konsep ini adalah tidak dipisahkannya prinsip yang "benar" dengan yang "salah" sebelum dilakukan (do) secara "benar". Artinya, terlepas dari apakah sesuatu hal itu "benar" atau "salah" semuanya dikerjakan "secara benar" atau telah sesuai dengan prosedur. Dalam kasus Enron, misalnya, pengelola perusahaan melalui teknik yang canggih dan meng-

3 Sebagai suatu system, corporate governance dapat didefinisikan sebagai 'the whole set of legal, cultural and institutional arrangements that determines what publicly traded corporations can do, who controls them, how that control is exercised, and how the risk and returns from the activities they undertake are allocated' (Blair 1995, p. 3).

4 Sebagai sebuah sistem, mekanisme CG memerlukan berbagai perangkat berikut ini (a) company law, (b) securities law, (c) listing rules, (d) accounting standards, (e) bankcruptcy and insolvency laws, (f) competition or anti-trust laws, (g) important of courts (judicial redress), (h) market institutions and practices, (i) codes of good governance (best practices), and (j) mechanisms for addressing investors/minority shareholder expectation (Luz 2001). 
gunakan prosedur formal yang legal, mampu melakukan "dandanan" (make-up) sedemikian rupa terhadap kinerja usaha perusahaan sehingga mampu menutupi kondisi perusahaan yang sebenarnya. Dibalik hal tersebut, sebagaimana terbukti belakangan, keadaan internal perusahaan ini jauh dari kondisi sehat (Zandstra 2002).

Berbeda dengan konsep ini, CG memberikan penekanan pada the right things sebelum dikerjakan secara benar. Berkaitan dengan ini hal yang paling mendasar adalah sebelum memutuskan atau melakukan sesuatu perlu dipertimbangkan apakah hal tersebut "benar" (right) atau "salah" (wrong) sebelum dilakukan (do) dengan "benar". Dengan demikian, konsep CG sama sekali tidak berlawanan dengan konsep manajemen, tetapi lebih bersifat saling mendukung satu sama lainnya. Tegasnya, melakukan "sesuatu secara benar" adalah penting, tetapi memutuskan apakah yang akan dilakukan itu adalah "sesuatu yang benar" merupakan hal yang lebih penting. Adalah sesuatu yang mudah diucapkan namun sulit untuk dilakukan jika kita berbicara mengenai kriteria suatu dikotomi antara sesuatu yang "benar" dengan "salah". Menurut penulis, hal ini lebih bermuara kepada masalah moralitas, dan dalam konteks CG, aplikasi dari dikotomi ini berkaitan dengan etika bisnis individu yang berada di dalam sebuah sistem (akan dibahas lebih detail pada bagian kendala penerapan CG).

\section{CG: KONSEP LAMA YANG MENJADI TREND KEMBALI}

Secara konseptual, keberadaan konsep CG dapat ditelusuri balik hingga ke akhir abad 18 masehi. Para ahli di bidang CG sepakat untuk menyatakan bahwa Adam Smith (1776) merupakan filosof pertama yang dianggap menjadi peletak dasar dalam memformalisasikan konsep CG. Melalui perkembangannya hingga permulaan abad ke 21, konsep CG telah melalui dua tahapan generasi (Denis \& McConnel 2003). Generasi pertama dibidani oleh Berle dan Means (1932) $)^{5}$ dengan penekanan pada konsekuensi dari terjadinya pemisahan antara kepemilikan dan kontrol atas suatu perusahaan modern. Pasangan lawyer ini berpendapat sejalan dengan berkembangnya perusahaan menjadi semakin besar, maka pengelolaan perusahaan yang semula dipegang oleh pemilik (owner-manager) harus diserahkan pada kaum professional. Dalam hal ini isu yang dianggap dominan adalah; perlunya suatu mekanisme untuk menjamin bahwa manajemen

5 Berle and Means (1932) dianggap sebagai ahli pertama yang memulai the modern debate mengenai konsep CG dengan gagasannya 'The Modern Corporation and Private Property'. Dalam perjalanannya, konsep CG dikembangkan dan menjadi masyhur oleh Schumpeter pada tahun 1947 serta dalam the managerial literature pada tahun 1960an, khususnya melalui John Kenneth Galbraith di tahun 1967 dalam bukunya 'The New Industrial State'. Namun penulis belum menemukan literatur yang mengklaim siapa yang pertama kali menggunakan istilah 'corporate governance'. 
(agent), yang merupakan orang gajian pemilik modal (principal), akan mengelola perusahaan sesuai dengan kepentingan pemilik. Pesan penting dari penjelasan ini adalah terdapatnya potensi konflik kepentingan (conflict of interests) antara pihak agent dan principal dalam suatu perusahaan.

Perkembangan signifikan dalam konsep CG pada tahapan generasi pertama ini ditandai dengan kemunculan para ekonom hampir setengah abad kemudian melalui Jensen dan Meckling (1976) ${ }^{6}$. Kedua ahli ini terkenal dengan teori ke-agenan (Agency Theory) ${ }^{7}$ yang menandai tonggak perkembangan riset yang luar biasa di bidang CG. Melalui teori ini, berbagai bidang ilmu sosial lainnya -seperti; sosiologi, manajemen strategik, manajemen, keuangan, akuntansi, etika bisnis, dan organisasi- mulai menggunakan pendekatan teori keagenan untuk memahami fenomena CG. Dengan demikian perkembangan CG telah menjadi multi dimensi dibanding periode sebelumnya, dimana pemanfaatan teori dimaksud masih didominasi oleh para ahli hukum (legal) dan ekonom (economist). Pada era generasi pertama ini pula muncul berbagai derivasi teori keagenan hasil dari sintesa -melalui proses dialektika- dari berbagai bidang keilmuan di atas. Beberapa diantaranya adalah; principal-agent theory, stakeholder theory, stewardship theory, maupun normative agency theory dan sebagainya.

Perkembangan yang secara efektif dianggap sebagai awal munculnya generasi kedua CG ditandai dengan hasil karya La-Porta dan koleganya pada tahun 1998 (Denis \& McConnel 2003). Secara signifikan LLSV8 mengidentifikasi kecenderungan terdapatnya konsentrasi kepemilikan perusahaan pada pihak-pihak tertentu. Berbeda dengan Berle dan Means (1932), menurut LLSV penerapan CG di suatu negara sangat dipengaruhi oleh kondisi perangkat hukum di negara tersebut dalam melindungi kepentingan berbagai pihak yang terkait dengan perusahaan, terutama pemilik minoritas. Jika sebelumnya konflik kepentingan dianggap terjadi antara pemilik modal (principal) dengan pengelola (agent), LLSV mempunyai ga-

6 Walaupun mampu menjadi inspirator terhadap pengembangan konsep CG secara lintas negara dan lintas bidang ilmu, mereka dianggap mempunyai kesamaan pandang dengan pendahulunya (Berle dan Means). Mereka juga memperkenalkan berbagai perangkat pengendali, baik internal maupun eksternal terhadap perusahaan sesuai dengan perkembangan pasar modal dan perangkat hukum yang semakin baik dibanding dengan periode sebelumnya.

7 Perspektif yang dimuat dalam artikel terkenal Jensen dan Meckling (1976), pada prinsipnya dibangun berdasarkan kajian beberapa ahli sebelumnya, seperti Ronald Coase (1937) dalam mendefinisikan konsep perusahaan, Oliver E. Williamson (1964/1985) mendiskusikan diskresi manajemen dan hubungannya dengan teori perusahaan, serta Armen Alchian dan Harold Demsetz (1972) yang mendiskusikan proses produktif kelompok di dalam memotivasi perusahaan (firm as ajoint (team) production)

8 La-Porta, Lopez-de-Silanes, Shleifer dan Vishny (disingkat LLSV) lebih dikenal dengan sebutan "the gang of four" di dalam literatur CG, khususnya dalam bidang international dan comparative CG. Para ahli ini memperkenalkan dan mempopulerkan pendekatan legal-keuangan (legal and finance approach) di dalam memahami fenomena CG. 
gasan (thesis) bahwa di berbagai negara lainnya diluar AS dan Inggris, kepemilikan perusahaan sangat terkonsentrasi9. Akibatnya, masih menurut LLSV, konflik kepentingan akan terjadi antara "si kuat" (pemilik mayoritas) dengan "si lemah" (pemilik minoritas). Menurut LLSV, sistem hukum yang tidak kondusif dan belum berpihak pada kepentingan umum, mengakibatkan konflik ini menjadi semakin tajam (intens) sehingga berpotensi merusak sistem perekonomian negara secara keseluruhan.

Pada tahapan generasi kedua inilah beberapa ahli menyadari misalnya OECD (1999)10 - bahwa terdapat perbedaan yang fundamental pada sistem CG di setiap negara, sehingga memunculkan konsep divergensi (divergence) dari CG sistem. Beberapa ahli mulai mengembangkan teorinya dengan mengaitkan hal tersebut pada masalah perbedaan budaya -misalnya Licht, Goldsmith \& Schwartz (2001)- serta sejarah perkembangan hukum dan struktur kelembagaan -seperti Bebchuk \& Roe (1999)sebagai faktor yang dominan. Namun demikian, terlepas dari berbagai tahapan perkembangan CG, permasalahan yang paling mendasar adalah terdapatnya konflik kepentingan (conflict of interests) yang berpotensi menimbulkan biaya keagenan (agency costs) yang sangat signifikan, sehingga dikhawatirkan akan menurunkan nilai perusahaan.

Berdasar uraian di atas dapat disimpulkan bahwa masalah CG akan selalu muncul jika terdapat konflik kepentingan di dalam satu perusahaan. Sementara konflik kepentingan disebabkan oleh adanya ketidak seimbangan "kekuatan" antara berbagai pihak yang berhubungan. Dalam kaitan ini Williamson (1985) berpendapat bahwa konflik demikian secara psikologis di dasarkan pada asumsi bahwa manusia bersifat oportunistik, yaitu kecenderungan untuk memanfaatkan kesempatan dengan tujuan memperoleh keuntungan dari suatu posisi/keadaan tertentu namun dengan merugikan pihak lainnya. Implikasinya, dengan terjadinya ketidakseimbangan kekuatan dan adanya peluang untuk mengeksploitasi sesuatu kepentingan, individu akan bersifat oportunistik serta akan berdampak luas pada terganggunya keseimbangan suatu sistem. Untuk itu dibutuhkanlah seperangkat aturan main yang jelas agar berbagai perangkat organisasi dalam sebuah sistem (CG system) dapat menjalankan fungsinya untuk menjamin

9 Bahkan di beberapa negara maju seperti Amerika dan Inggris sendiri juga telah muncul fenomena baru dengan terkonsentrasinya kepemilikan saham pada lembaga keuangan (institutional investors). Misalnya di AS, lembaga investasi seperti The California Public Employees' Retirement System (CalPERS) yang ikut berperan aktif di dalam mengadvokasi perlunya penyelenggaraan CG secara lebih baik untuk kepentingan semua pihak, termasuk investor lembaga keuangan.

10 OECD (1999) dalam kaitan ini terkenal dengan slogannya 'no-one-size-fits-all' CG system. Pandangan ini di dasarkan pada adanya interaksi yang dinamis antar berbagai factor eksternal dan internal dari suatu CG system, yang merefleksikan spesifikasi dari struktur pasar, tradisi dari system hukum, regulasi, serta nilai-nilai budaya dan social kemasyarakatan. 
terjaganya kepentingan berbagai pihak yang berhubungan dengan perusahaan. Dengan berjalannya mekanisme ini, diharapkan dapat menghasilkan dampak lanjutan yang positif terhadap perkembangan perekonomian suatu negara untuk tercapainya kemakmuran masyarakat (the wealth of the nation) seperti kondisi yang dimaksud oleh Adam Smith.

\section{KONDISI PENERAPAN CG DI INDONESIA}

Para ahli sepakat menyatakan bahwa sistem CG yang dianut Indonesia mengikuti pola Continental European system. Klaim ini dibuktikan dengan berbagai ciri berikut ini (e.g. La Porta et al. 1998; Husnan 2001; Claessens, Djankov \& Lang 2000); (1) dianutnya sistem dan perangkat hukum yang bersumber pada tradisi French-Civil Law, (2) digunakannya dua struktur dewan perusahaan (two-tier board system), (3) terkonsentrasinya kepemilikan perusahaan (concentrated ownership structure), dan (4) dominannya sumber pembiayaan perusahaan dari luar perusahaan berupa hutang (external financing). Munculnya berbagai karakteristik ini, dalam hubungannya dengan sistem CG yang dianut Indonesia, dapat dijelaskan dengan menggunakan teori path-dependence (Bebchuk \& Roe 1999).

Menurut teori ini struktur suatu perusahaan dan ekonomi di suatu negara sangat ditentukan oleh struktur awal dimulainya kegiatan perekonomian negara tersebut, dan pada tahapan berikutnya struktur hukum dan perundang-udangan akan berjalan mengikuti pola ini. Sejarah membuktikan munculnya perusahaan berskala relatif besar di Indonesia dimulai pada periode setelah kemerdekaan, dengan dinasionalisasikannya berbagai perusahaan milik Belanda oleh pemerintah Indonesia (Husnan 2001). "Penggantian" kepemilikan ini hanya ditandai dengan "pemindahan" kepemilikan, karena sejak saat itu "struktur perusahaan" maupun hukum perusahaan serta perangkat lainnya- menggunakan sistem yang di ciptakan oleh Belanda. Walaupun di akhir paruh 1990an telah dikeluarkan berbagai undang-undang baru -misalnya Undang-undang tentang Perseroan Terbatas atau Undang-undang Kebangkrutan- namun semua perundang-udangan dan praktik bisnis di Indonesia masih berdasarkan pada pola yang di adopsi dari Belanda (Lindsey 2002). Tegasnya, sistem pengelolaan perusahaan di Indonesia sangat dipengaruhi oleh faktor ketergantungan (path dependencies) pada struktur perusahaan dan hukum yang diwarisi dari Belanda.

Sebagaimana dijelaskan pada bagian sebelumnya, problem mendasar dari CG yang dimulai sejak era Adam Smith, adalah akibat dari pemisahan antara kepemilikan dan pengendalian terhadap perusahaan. Kondisi ini jelas akan menimbulkan "konflik kepentingan" yang dapat mempengaruhi upaya pencapaian tujuan perusahaan. Untuk itu dibutuhkan 
suatu mekanisme yang bekerja di dalam suatu sistem yang berfungsi sebagai "kekuatan pengendali" (disciplinary forces) agar konflik kepentingan tidak merugikan perusahaan ataupun berbagai pihak lainnya yang mempunyai kepentingan lain dengan perusahaan (stakeholders). Di dalam setiap sistem CG, mekasnime kontrol yang bekerja dapat dibedakan atas dua kelompok; pertama, mekanisme eksternal dari perusahaan (the market for corporate control), serta kedua mekanisme yang bersifat internal dalam perusahaan (internal control mechanisms).

Berdasarkan pendekatan "no-one-size-fits-all" (OECD 1999), mekanisme kontrol dalam sistem CG yang dianut oleh suatu negara mempunyai karakteristik yang berbeda dengan negara lainnya. Misalnya, diberbagai negara Anglo-Saxon yang sistem keuangannya berbasis pasar (market-oriented) dapat lebih mengandalkan mekanisme yang pertama (Moerland 1995). Alasannya adalah karena hukum pasar (pasar modal, produk dan tenaga kerja) akan "mendisiplinkan" perusahaan yang tidak mematuhi aturan CG, disamping mekanisme internal yang juga bekerja secara baik (properly). Sebaliknya di negara-negara yang sedang berkembang, dan umumnya mempunyai sistem keuangan berbasis jaringan (network-oriented), belum dapat sepenuhnya mengandalkan mekanisme pasar sebagai perangkat kontrol. Salah satu alasannya adalah karena mekanisme pasar dan perangkat pendukungnya belum mempunyai kekuatan yang cukup untuk mendisiplinkan ${ }^{11}$ perusahaan, sebagaimana halnya kondisi di negara maju. Hal yang sama juga terjadi pada mekanisme kontrol internal yang relatif tidak efektif, misalnya karena tidak independennya dewan komisaris dari intervensi pemilik saham mayoritas. Secara umum beberapa karakteristik utama CG sistem yang ditemukan di Indonesia (Lukviarman 2001), dapat dilihat pada bahagian lampiran tulisan ini.

\section{KENDALA PENERAPAN CG DI INDONESIA}

Uraian yang telah dipaparkan sebelumnya menunjukkan bahwa Indonesia memiliki sistem CG yang relatif spesifik. Walaupun berbagai pola yang berhubungan dengan sistem tersebut -seperti perangkat hukum dan struktur perusahaan- masih mengacu kepada pola Belanda, namun penerapan CG di Indonesia berbeda secara signifikan dengan negara-negara kontinental Eropa lainnya (Husnan 2001). Survey yang dilakukan dalam beberapa tahun terakhir (La Porta 1998; CSLA 2001) membuktikan bahwa diantara sembilan negara di Asia, Indonesia berada di peringkat terakhir

11 Salah satu penyebabnya adalah terkonsentrasinya kepemilikan perusahaan yang berdampak pada rendahnya proporsi kepemilikan publik (Lukviarman 2003b), sehingga mekanisme pasar seperti merger dan akuisisi dalam mendisiplinkan perusahaan belum mampu bekerja secara optimal. 
dalam masalah kondusifnya iklim berusaha, terutama menyangkut pelaksanaan dan kepastian hukum. Dibanding Filipina, yang juga menganut sistem perundang-undangan berbasis French Civil-law tradition, peringkat Indonesia secara rata-rata masih lebih rendah. Implikasinya adalah bahwa masalah hukum bukan satu-satunya faktor yang dominan atau terdapatnya faktor lain yang ikut berinteraksi di dalam CG sistem di Indonesia yang turut mempengaruhi efektifitas penerapannya ${ }^{12}$.

Dari sudut legal-formal, Tabalujan (2002) berpendapat bahwa Indonesia sudah mempunyai perangkat hukum dan lembaga pendukungnya yang cukup, bahkan sudah melebihi jumlah yang seharusnya dibutuhkan. Menurut ahli ini, yang dibutuhkan Indonesia saat ini adalah perubahan yang mendasar terhadap budaya hukum (legal culture) ${ }^{13}$, sehingga masyarakat dapat menjadi lebih taat hukum serta taat asas. Kondisi ini dibutuhkan agar perangkat hukum dan institusi pendukungnya dapat berfungsi sesuai dengan tujuan semula yang telah ditetapkan. Tabalujan (2002) lebih lanjut menjelaskan bahwa salah satu alasan tidak berfungsinya hukum di negara berkembang, terutama Indonesia, karena hukum yang diadopsi dari negara Barat tersebut berbenturan dengan budaya lokal/hukum informal (legal culture) sebagai akibat dari tidak diperhatikannya faktor budaya masyarakat Indonesia. Tabalujan (2002) berkeyakinan bahwa budaya lokal seperti "patrimonialism"14 merupakan elemen penting budaya masyarakat Indonesia yang berperanan dalam mempengaruhi perilaku CG di Indonesia. Implikasi dari pernyataan ini adalah bahwa nilai budaya tradisional lebih berperan sebagai aturan yang dominan, dibandingkan dengan aturan hukum yang terinstitusionalisasi secara legal-formal.

Lebih dominannya pengaruh nilai-nilai informal dibanding aturan legal-formal, menurut penulis, tidak akan membawa dampak negatif jika keduanya didasarkan pada prinsip dasar moral yang jelas. Karena secara umum, semua aturan disusun dengan berpanduan pada virtue yang dianggap dapat meningkatkan kemaslahatan umat manusia, atau demi kepentingan bersama. Dengan dasar ini, penulis melihat bahwa keduanya mempunyai tujuan yang sama; "untuk menjaga agar segala sesuatu dikerjakan

12 Efektifitas penerapan CG ditandai oleh terdapatnya keseimbangan (balance) dari berbagai perangkat (sub-system) yang terdapat di dalam mekanisme system CG.

13 Didalam suatu sistem kemasyarakatan, Lev (1972) membagi hukum menjadi hukum formal (legal system) beserta institusinya, dan hukum non-formal (legal culture) yang merupakan dasar budaya dari suatu sistem hukum. Keduanya saling berhubungan di dalam menentukan aturan main (rule of law) dan berbagai lembaga pendukungnya di dalam suatu masyarakat.

14 "Patrimonialism" merupakan salah satu konsep sosiologi yang bersumber dari ide dasar Max Weber. Di dalam konteks CG, aplikasi dari konsep ini dapat dilihat dalam bentuk dominannya pengaruh dan tingkat kepatuhan masyarakat terhadp nilai-nilai sosial-kekeluargaan (aturan informal di dalam suatu kelompok), dibandingkan dengan aturan legal formal. 
secara benar, sesuai dengan tujuannya dan tanpa merugikan pihak lain". Namun deviasi dapat terjadi di dalam praktik, dimana dominasi sikap opportunistik para pelaku bisnis sebagaimana disinyalir oleh Williamson (1985) mengakibatkan beberapa pihak memanfaatkan peluang dengan merugikan pihak lainnya. Di dalam konteks CG, hal ini jelas berpotensi akan mengganggu keseimbangan sistem, sehingga mekanisme kontrol harus bekerja untuk melakukan penyesuaian kembali. Namun demikian, karena umumnya mekanisme kontrol CG yang ada tidak dapat bekerja secara optimal di Indonesia (Lukviarman 2001), maka pihak mayoritas yang "sangat kuat" tidak mempunyai "kekuatan penyeimbang". Tegasnya, disebabkan oleh berbagai pihak yang berhubungan dalam sistem tersebut tidak mengikuti aturan main yang ada, maka sebagaimana metofora "papan catur" umat manusia Adam Smith, terjadilah disorder yang akan mengakibatkan seluruh masyarakat menerima dampak negatifnya.

Berdasarkan uraian di atas, dari suatu sisi yang paling manusiawi, penulis berpendapat bahwa kendala paling mendasar dalam penerapan CG di Indonesia berhubungan dengan moral dan etika. Misalnya, perusahaan publik di Indonesia umumnya berpola kepemilikan yang terkonsentrasi (Lukviarman 2003a) dengan basis hubungan keluarga (family ownership) serta pada umumnya bergabung dalam suatu jaringan kelompok bisnis berbasis keluarga (family business groups). Dengan bercirikan keluarga sebagai pemilik mayoritas perusahaan, maka kekuatan tawar menawar pihak ini menjadi sangat kuat. Terlepas dari efektif atau tidaknya perangkat hukum dan peraturan yang ada mampu membatasi ruang gerak mereka, tanpa basis moral dan etika yang kuat, peluang untuk mendahulukan kepentingan kelompok -pemilik mayoritas- dengan mengorbankan kepentingan pihak lain -misalnya pemilik minoritas, bahkan masyarakat/publikmenjadi sangat besar. Fenomena sakitnya berbagai bank di Indonesia beberapa waktu setelah periode krisis, sehingga harus dirawat BPPN, dapat dijadikan suatu kasus untuk mengamati terjadinya praktik ini.

Sudah menjadi rahasia umum, bahwa setiap kelompok bisnis/konglomerat di Indonesia paling tidak memiliki atau mempunyai hubungan afiliasi paling tidak dengan satu buah bank (Patrick 2002). Secara teoretis, sebagai lembaga yang mendasarkan aktivitasnya pada asas "kepercayaan", bank berfungsi sebagai mediator dalam memfasilitasi kepentingan para deposan/debitur dengan kreditur. Namun dalam kasus ini, kepercayaan dimaksud "dimanfaatkan" oleh pemilik mayoritas kelompok bisnis dimana lembaga perbankan ini terafiliasi, dengan menjadikan lembaga perbankan tersebut sebagai "kasir" atau "sapi perahan" (cash cows) bagi kepentingan mereka. Dengan memanfaatkan momentum deregulasi per- 
bankan, para konglomerat ${ }^{15}$ ini melakukan berbagai praktik curang dengan cara menyerap dana masyarakat (deposan) untuk kemudian menyalurkankannya ke perusahaan lainnya yang berada di bawah bendera kelompok bisnis mereka sendiri. Dengan cara inilah para konglomerat tersebut dapat memperlebar atau melakukan diversifikasi terhadap "gurita" bisnis mereka, tanpa memperhatikan etika. Ironinya, perilaku ini bahkan berlangsung ditengah adanya aturan legal formal yang membatasi ruang gerak mereka (BMPK $\left.{ }^{16}\right)$. Sekali lagi, sekuat apapun aturan yang ada, landasan penting dalam hal ini adalah seberapa jauh moral dan etika digunakan di dalam proses pengambilan keputusan.

\section{CG DAN ETIKA BISNIS}

Sternberg (1994) mendefinisikan etika bisnis sebagai suatu bidang filosofi yang berhubungan dengan pengaplikasian ethical reasoning terhadap berbagai praktik dan aktivitas dalam berbisnis. Dalam kaitan ini, etika bsinis merupakan upaya untuk mencarikan jalan keluar atau paling tidak mengklarifikasikan berbagai moral issues yang secara spesifik muncul atau berkaitan dengan aktivitas bisnis tersebut. Dengan demikian prosesnya dimulai dari analisis terhadap the nature and presuppositions of business hingga berimplikasi sebagai prinsip-prinsip moral secara umum dalam upaya untuk mengidentifikasi apa yang "benar" di dalam berbisnis. Sternberg (1994) memberikan argumen bahwa prinsip-prinsip moral ini akan menjadi kriteria di dalam menilai berbagai tingkah laku bisnis yang dianggap acceptable, yang akan diaplikasikan secara konsisten oleh seluruh pelaku bisnis, dimana dan kapan saja.

Untuk menjelaskan konsep etika bisnis, Sternberg (1994) memperkenalkan pendekatan teological (teological approach) di dalam memahami hubungan antara konsep CG dengan etika bisnis (business ethic). Secara umum, pendekatan dimaksud merupakan proses mengidentifikasi dan menjelaskan berbagai aktivitas manusia dengan berpedoman pada tujuan (ends/aims/goals/objectives/purposes) di dalam melakukan sesuatu aktivitas. Artinya di dalam penilaian etika bisnis pemahaman terhadap "tujuan" dari suatu aktivitas akan sangat menentukan baik atau tidaknya (goodness) aktivitas tersebut. Dengan kata lain 'just as a good object is identified by reference to the object's purpose, what counts as the proper conduct of an activity depends on the activity's purpose' (Sternberg 1994, p. 4).

15 Untuk membedakannya dengan kelompok bisnis (konglomerat) yang mempunyai etika bisnis relatif lebih baik, Kwik Kian Gie menjuluki para konglomerat lainnya dengan istilah "konglomerat hitam".

16 Pemerintah, melalui Bank Indonesia, sebagai pengemban amanat untuk mengawasi berbagai aktivitas perbankan di Indonesia, menetapkan adanya Batasan Maksimum Pemberian Kredit (BMPK) atas suatu bank kepada berbagai perusahaan yang terafiliasi dengan mereka. 
Tujuan perusahaan ${ }^{17}$ dapat didefinisikan sebagai upaya untuk "memaksimumkan kesejahteraan si pemilik dalam rentang waktu jangka panjang melalui aktivitas penjualan barang dan/atau jasa18" (Sternberg 1994, p. 32). Prinsip etika bisnis dalam kaitan ini berhubungan dengan berbagai upaya untuk menggabungkan berbagai nilai-nilai dasar (basic values) dalam perusahaan, agar berbagai aktivitas yang dilaksanakan dapat mencapai tujuan. Secara lebih jelas, mekanismenya berjalan sebagai berikut. "Memaksimumkan kesejahteraan si pemilik dalam jangka panjang", berhubungan dengan dimensi waktu yang relatif panjang serta menyangkut sustainability. Hal ini membutuhkan adanya "kepercayaan" atau "saling mempercayai" (trust) dari berbagai pihak yang berhubungan dengan perusahaan (stakeholders). Kalimat "kesejahteraan pemilik" merupakan derivasi dan perwujudan dari "hak kepemilikan" (ownership) yang muncul dari adanya penghargaan (respect) terhadap "kepemilikan pribadi" (property rights).

Uraian di atas lebih memberikan penekanan pada "hak" si pemilik atas perusahaannya, tanpa memberikan bobot berarti pada sisi "kewajiban" sebagai pemilik perusahaan maupun perusahaan sebagai organisasi. Dari sisi lain mata uang yang sama, pemilik perusahaan juga merupakan moral agents yang melakukan "aktivitas" di dalam serta "berintekasi" dengan masyarakat, sehingga mempunyai tanggungjawab moral terhadap lingkungannya. Tanggungjawab moral sebagai "pemilik perusahaan" mengharuskan mereka untuk mempertimbangkan kepentingan pihak lain yang berhubungan dengan aktivitas perusahaan (stakeholders). Dengan demikian, tanggungjawab ini relatif terbatas pada berbagai pihak seperti pemilik minoritas, karyawan, investor, kreditur, supplier, konsumen dan sebagainya. Sementara tanggungjawab moral sebagai "perusahaan" membawa implikasi perlunya kepekaan perusahaan di dalam membuat berbagai keputusan ${ }^{19}$ yang membawa dampak sosial kemasyarakatan yang lebih luas. Luasnya cakupan tanggungjawab ini biasanya dikemas melalui

17 Tujuan (objective) perusahaan memberikan spesifikasi apa yang akan dicapai oleh para pembuat keputusan (manajemen) dan memberikan ukuran di dalam memilih berbagai alternatif keputusan yang tersedia.

18 Tujuan ini didasarkan pada konsep Shareholder Wealth Maximisation (SWM) model yang biasa di anut oleh berbagai perusahaan di negara-negara Anglo-Saxon. Sementara untuk negara Continental European dan Jepang, tujuan perusahaan pada umumnya lebih mengacu kepada Corporate Wealth Maximisation (CWM) model atau dikenal juga dengan Stakeholder Capitalism Model. Pada model kedua (CWM) definisi corporate wealth dianggap lebih luas --mencakup proses produksi, profisiensi teknologi, kapabilitas pemasaran serta administrasi, posisi perusahaan di dalam pasar serta sumber daya manusia-- dibanding hanya dengan tujuan utama untuk memaksimumkan shareholder wealth -yang biasanya diukur dengan peningkatan harga saham di pasar modal-- pada SWM model.

19 Di dalam konteks etika bisnis, dikenal tiga pendekatan/model dalam pengambilan keputusan perusahaan (1) utilitarian model, (2) moral rights model, and (3) justice model. 
mekanisme "tanggungjawab sosial perusahaan"20 (Corporate Social Responsibility/CSR).

Walaupun secara konseptual terdapat pembedaan klasifikasi tanggungjawab moral antara "pemilik" dengan "perusahaan", menurut penulis keduanya saling berhubungan dan mempunyai dasar moralitas yang sama. Dalam hal ini penulis menggunakan argumen berdasarkan salah satu prinsip keutamaan (virtue) yang dikemukan Socrates bahwa "keutamaan itu satu adanya". Walaupun kaum sofis berpendapat bahwa "kebenaran" adalah bersifat relatif, semu serta sangat tergantung pada siapa yang memandangnya, namun pemikiran yang lebih mendalam dengan menggunakan moral reasoning akan mampu menemukan jawaban (moral judgement) ${ }^{21}$ bahwa hanya ada satu kebenaran. Menurut Kusen (2002, 227) "kebenaran tidak terikat oleh ruang dan waktu. Kapan, dimana, dan siapapun yang memandangnya kebenaran itu tetap kebenaran dan ia satu adanya". Implikasi penyataan ini jika dikaitkan dengan runtuhnya kejayaan Enron di AS dapat dilihat pada kenyataan bahwa memanipulasi data-data keuangan untuk kepentingan apapun dan siapapun adalah "salah" (tidak benar), jika ditinjau dari berbagai dimensi ini. Hal ini memberikan justifikasi bahwa sesuatu kebenaran -dan dalam hal ini berkaitan dengan etika bisnis- adalah universal adanya.

Dalam kaitannya dengan penerapan CG di Indonesia, jelas bahwa berbagai praktik seperti penggelembungan nilai proyek untuk memperoleh pembiayaan bank, memperoleh izin usaha tanpa harus melalui prosedur standar, tingkat pencemaran lingkungan yang di luar ambang batas toleransi, jelas merupakan praktik yang salah. Dalam masalah ini problematika paling umum biasanya terjadi melalui pertentangan antara "kepentingan pribadi dan kelompok atau keluarga" disatu sisi dengan "kepentingan masyarakat luas/publik" di sisi lainnya. Tanpa dasar moralitas dan etika yang baik serta tingginya sifat opportunistik yang dimiliki individu, menyebabkan kalangan pemilik perusahaan bersikap menjadi ethnocentric. Dengan dasar demikian mereka akan mendahulukan kepentingan pribadi

${ }^{20}$ Secara sederhana, tanggung jawab sosial perusahaan dapat diartikan sebagai kewajiban dari pengeIola bisnis atau manajer untuk memilih berbagai alternatif keputusan serta menjalankannya dengan cara yang dapat memberikan manfaat bagi kepentingan perusahaan dan masyarakat umum. Di dalam kaitan ini pengelola perusahaan sering dihadapkan pada dilema etika (ethical dilemmas) yang timbul dari konflik kepentingan berbagai pihak yang berhubungan dengan perusahaan. Untuk itu, etika bisnis akan mengarahkan para manajer di dalam mempertimbangkan berbagai alternatif keputusan yang ada serta memilih keputusan bisnis yang "benar".

21 Dalam hubungannya dengan etika bisnis, pertimbangan etika (ethical judgments) digunakan dalam pengambilan keputusan bisnis melalui tahapan berikut. (1) Mengumpulkan berbagai informasi factual, (2) Melakukan analisis terhadap berbagai factor yang ada untuk menentukan nilai moral (moral values) yang paling sesuai (most appropriate), dan (3) Melakukan ethical judgement berdasarkan rightness atau wrongness dari tindakan atau kebijakan yang akan dihasilkan (porposed action or policy). 
dan/atau kelompok di atas kepentingan orang banyak, walaupun tindakan yang dilakukan adalah salah. Tindakan ini semakin membahayakan jika penegakan hukum dan aturan perundangan lainnya yang ditujukan sebagai mekanisme kontrol perilaku pebisnis, tidak dapat ditegakkan. Kondisi inilah yang pada akhirnya menyebabkan rapuhnya sendi-sendi perekonomian, melemahnya institusi, mandulnya sistem hukum, yang pada gilirannya akan merusak sistem perekonomian nasional secara keseluruhan.

Secara umum dapat disimpulkan bahwa, disamping berbagai masalah operasional yang berkaitan dengan berbagai infrastruktur yang diperlukan untuk mendukung terlaksananya CG secara baik, kendala paling utama justru berada pada sisi "manusianya" atau individu yang berada dalam sistem tersebut. Argumen ini didasarkan pada kenyataan bahwa seberapa canggihpun perangkat sistem yang dimiliki tidak akan mampu memberikan hasil optimal, jika tidak diiringi oleh kemauan para individu/pebisnis untuk patuh atau taat asas terhadap aturan main yang telah digariskan. Lebih lanjut, karena penekanan sistem CG berdasarkan pada prinsip "keseimbangan", maka kekuatan pengendali untuk melakukan checks and balances terhadap berbagai aktivitas bisnis mutlak diperlukan. Melalui mekanisme CG yang dirancang sesuai dengan karakteristik suatu masyarakat, kekuatan ini hanya akan berfungsi optimal jika semua individu yang terkait dengan berbagai elemen dalam sistem tersebut berpedoman pada aspek moralitas atau etika di dalam melaksanakan fungsi dan tanggungjawabnya masing-masing. Untuk itu, diperlukan adanya suatu pedoman etika bisnis yang jelas dan terinci agar setiap pelanggaran moral bisa dipertanggung jawabkan di hadapan hukum formal. Jika tidak, sejarah akan mengulanginya.

\section{PENUTUP}

CG merupakan konsep lama yang kembali populer dengan berbagai pendekatan baru, sesuai dengan perkembangan sosial dan kemasyarakatan, khususnya yang berhubungan dengan kemajuan praktik bisnis. Dengan demikian, konsep CG bersifat dinamis dan akomodatif terhadap berbagai perubahan yang bertujuan untuk menjaga agar perubahan dimaksud tidak mengganggu keseimbangan sistem yang ada. Kemauan berbagai individu yang terkait dengan sistem CG untuk taat asas dan taat hukum serta berpedoman pada etika bisnis di dalam melaksanakan aktivitasnya, akan sangat menentukan berjalannya sistem yang ada secara lebih efektif.

Sebagai tenaga akademisi di institusi pendidikan tinggi, penulis ikut bertanggungjawab di dalam melahirkan intelektual, praktisi dan profesional yang akan berhubungan dengan aktivitas bisnis di dalam masyarakat. Untuk itu penulis mempunyai kewajiban untuk mendidik serta mem- 
bekali mahasiswa dengan pendidikan moral serta etika bisnis agar menjadi pebisnis yang beretika serta konsisten dengan norma-norma yang berlaku. Hal ini sejalan dengan harapan Afiff (2001, p. 77) agar lembaga perguruan tinggi "lebih mampu mencetak insan akademis yang kecerdasan intelektualnya setara dengan kepekaan nuraninya".

\section{Krakteristik Umum Penerapan CG Sistem di Indonesia}

1. Kepemilikan perusahaan terkonsentrasi pada individu atau keluarga, sehingga pihak ini mempunyai pengaruh kuat untuk menentukan arah perusahaan. Akibatnya problem keagenan (the agency problem) lebih terarah pada benturan kepentingan antara pemilik mayoritas ini dengan pemilik minoritas. Secara umum pemilik saham minoritas selalu berada pada posisi yang lemah.

2. Kepemilikan saham dengan penguasaan mayoritas oleh keluarga, diikuti dengan ikut campurnya anggota keluarga atau orang dekat kepercayaannya untuk menduduki posisi direksi dan/atau komisaris di dalam suatu perusahaan. Akibatnya posisi komisaris, yang seharusnya menjadi pengawas manajemen, menjadi tidak kapabel serta tidak independen di dalam menjalankan tugasnya.

3. Kepemilikan saham keluarga juga diikuti dengan berkembangnya kelompok bisnis keluarga berpola konglomerat (conglomeration) dengan bidang usaha yang sangat ter-diversifikasi. Berbagai perusahaan yang menjadi anggota kelompok bisnis tersebut dikuasai melalui "penguasaan bertingkat dengan pola piramida" (pyramidal ownership structure).

4. Perusahaan publik di Indonesia pada umumnya mempunyai tingkat hutang yang sangat besar dan sebahagian besar dalam bentuk mata uang asing yang tidak dilindung-nilaikan (un-hedge), sehingga sangat rentan terhadap perubahan kondisi perekonomian. Pada beberapa kasus, dana pinjaman yang diperoleh dialokasikan pada kegiatan investasi lainnya yang tidak produktif, sehingga menurunkan nilai perusahaan.

5. Pasar modal relatif kecil dan tidak "likuid" sehingga tidak mampu secara efektif berperan sebagai mekanisme kontrol eksternal dalam upaya penerapan prinsip CG. Untuk mengatasinya, kelompok bisnis (konglomerat) menjadikan organisasi ini sebagai internal capital market dalam memfasilitasi pemindahan dana dari berbagai perusahaan dalam kelompok bisnis mereka.

6. Kombinasi antara relatif kecilnya pasar modal Indonesia dengan sedikitnya proporsi kepemilikan perusahaan (dalam bentuk) saham yang dijual kepada publik, membuat pemilik mayoritas berada pada posisi yang sangat kuat. Terutama dengan tidak mampunya mekanisme kontrol eksternal lainnya, seperti merger dan akuisisi, untuk ikut mendisiplinkan perusahaan yang tidak menerapkan prinsip CG yang sehat.

7. Lemahnya penegakan hukum dan lembaga pendukungnya di dalam menjaga berjalannya sistem secara benar, sesuai dengan fungsi yang telah ditetapkan. Kondisi ini semakin memperlemah pemilik minoritas namun, sebaliknya, akan memperkuat posisi pemilik saham mayoritas untuk mengeksploitasi sumber daya perusahaan untuk kepentingannya, namun merugikan kepentingan pihak lainnya (terutama pemegang saham minoritas).

8. Belum terdapat upaya perbaikan menyeluruh yang mencakup pembenahan seluruh komponen sistem CG guna mendukung terlaksananya penerapan mekanisme kontrol untuk menjamin berjalannya sistem ini secara seimbang dan berkesinambungan.

Sumber: Lukviarman (2001) 


\section{DAFTAR PUSTAKA}

Afiff, F. 2001, 'Kebangkitan Pendidikan Moral dan Etika Bisnis di Perguruan Tinggi', Jurnal Universitas Paramadina, vol. 1, no. 1, pp. 72-78.

Alchian, A.A. \& Demsetz, H. 1972, 'Production, Information Costs, and Economic Organization', American Economic Review, vol. 62, No. 5, pp. 777-795.

Asian Development Bank/A.D.B. 2000, 'Corporate Governance and Finance in East Asia: a Study of Indonesia, Republic of Korea, Malaysia, Philippines, and Thailand', Consolidated Report, vol. 1, The Asian Development Bank, Manila.

Bebchuk, L.A. \& Roe, M. J. 1999, 'A Theory of Path Dependence in Corporate Ownership and Governance', Stanford Law Review, vol. 52, no. 127, pp. 127-169.

Berglof, E. 1990, 'Capital Structure as a Mechanism of Control: a Comparison of Financial Systems', dalam M. Aoki, B. Gustafson \& O. E. Williamson (Eds.), The Firm as a Nexus of Treaties, Sage, London, pp. 237-262.

Berle, A.A. \& Means, G.C. 1932/1997 The Modern Corporation and Private Property, Transaction Publishers, New Brunswick.

Blair, M.M. 1995, 'Ownership and Control: Rethinking Corporate Governance for the Twenty-frst Century', The Brooking Institutions, New York.

Claessens, S., Djankov, S. \& Lang, L. 2000, 'The Separation of Ownership and Control in East Asian Corporations', Journal of Financial Economics, vol. 58, no. 1-2, pp. 81-112.

Coase, R. 1937 'The Nature of the Firm' (online version) diakses 20 Oktober 2003 dari http://people.bu.edu/vaguirre/courses/bu332/nature firm.pdf

Credit Lyonnais Securities Asia/C.S.L.A. 2001, 'Saints and Sinners: Who's got Religion?'. Corporate Governance Watch-Corporate Governance in Emerging Markets, CLSA Publications, Hong Kong.

Denis, D.K. \& McConnel, J.J. 2003, 'International Corporate Governance', Journal of Financial and Quantitative Analysis, vol. 38, no. 1, pp. 1-36.

Husnan, S. 2001, 'Indonesia' dalam J. Zhuang, D. Edwards, M.V. Capulong (Eds.) Corporate Governance and Finance in East Asia: a Study of 
Indonesia, Republic of Korea, Malaysia, Philippines, and Thailand, Country Studies, vol. 2, The Asian Development Bank, Manila.

Jensen, M.C. \& Meckling, W.H. 1976, 'Theory of the Firm: Managerial Behaviour, Agency Costs and Ownership Structure', Journal of Financial Economics, vol. 3, no. 4, pp. 305-360.

Kurniawan, D.M. \& Indirantoro, N. 2000, 'Corporate Governance in Indonesia', Conference Paper at the Second Asian Roundtable on Corporate Governance, diakses 19 Agustus 2001, dari http://www.oecd.org/dataoecd/6/62/1931154.pdf.

Kusen 2002, 'Konsep Filosofis Manusia Dalam Al-Qur'an: Tinjauan Sejarah Adam A.S.', Jurnal Universitas Paramadina, vol. 1, no. 3, pp. 224232.

La Porta, R., Lopez-de-Silanes, F., Shleifer, A. \& Vishny, R. 1998, 'Law and Finance', Journal of Political Economy, vol. 106, no. 6, pp. 1113 1155.

Lev, D.S., 1972, 'Judicial Institutions and Legal Culture in Indonesia', in C. Holt (ed) Culture and Politics in Indonesia, Cornell University Press, Ithaca, pp. 246-318.

Licht, A.N., Goldsmith, C. \& Schwart, S.H. 2001, 'Culture, Law and Finance: Cultural Dimensions of Corporate Governance', diakses 12 September 2003, dari http://papers.ssrn.com/sol3/papers.cfm?abstract id=277613

Lindsey, T. 2002 'History Always Repeats? Corruption, Culture and Asian Values' dalam T. Lindsey \& H. Dick (Eds.), Corruption in Asia: Rethinking the Governance Paradigm, Federation Press, Sydney, pp. 1-23.

Lukviarman, N. 2001, 'Key Characteristics of Corporate Governance: The Case of Indonesia', Working Paper, No. 01-01, Graduate School of Business, Curtin University of Technology, Perth.

Lukviarman, N. 2003a, 'Family Ownership and Corporate Governance', Procceding of the GSB Doctoral Conference 2003, November.

Lukviarman, N. 2003b, 'Concentrated Ownership and Corporate Governance: The Case of Indonesia', Procceding of the Conference on Pursuing "One-Best Way" Models of Good Governance, December.

Luz, J. M. 2001, 'Managing Corporate Governance in Asia: Legal and Regulatory Environment', Conference Paper, International Conference on Governance Reform; East Asia and China, Beijing- China, November 1-2. 
Moerland, P.W. 1995, 'Alternative Disciplinary Mechanism in Different Corporate Systems', Journal of Economic Behavior and Organization, vol. 26, no. 1, pp. 17-34.

National Committee on Corporate Governance/N.C.C.G. 2000, 'Code for Good Corporate Governance', Version 3.2, diakses 23 Juli 2002, dari

http://www.ecgi.org/codes/country documents/indonesia/ins cgcg may 2000.pdf

Organization for Economic Co-operation and Development/O.E.C.D. 1999, 'OECD Principles of Corporate Governance', The OECD, Paris.

Patrick, H. 2002 'Corporate Governance and the Indonesian Financial System: a Comparative Perspective', APEC Study Center Columbia Business School, Discussion paper No. 16, Retrieved: July 10, 2003, from http://www.columbia.edu/cu/business/apec/publications/hpatrick3. $\underline{\text { PDF }}$

Robins, F. 2002 'Impact of the Asian Crisis on Capitalism in Post-crisis Asian Business Environments', in U.C.V. Haley \& F. Richter (eds.), Asian Post Crisis Management, Palgrave, Hampshire, pp. 321352.

Smith, A. 1759/1976, The Theory of Moral Sentiments, Clarendon Press, Oxford.

Smith, A. 1776/1976, The Wealth of Nations, Clarendon Press, Oxford.

Sternberg, E. 1994, Just Business: Business Ethics in Action, Warner Books, London.

Tabalujan, B.S. 2002, 'Why Indonesian Corporate Governance FailedConjectures Concerning Legal Culture', Columbia Journal of Asia Law, vol. 15, no. 2, pp. 141-171.

Takala, T. 1998, 'Plato on Leadership', Journal of Business Ethics, vol. 17, no. 7, pp. 785-798

Williamson, O.E. 1985, The Economic Institutions of Capitalism; Firms, Markets, Relational Contracting, The Free Press, New York.

Zandstra, G. 2002, 'Enron, Board Governance and Moral Failings', Corporate Governance, vol. 2, no. 2, pp. 16-19. 